\title{
Nurses' Performance Assessment Based On Nursing Clinical Authority: A Qualitative Descriptive Study
}

\author{
Aisyah Supri $^{1}$, Rini Rachmawaty ${ }^{2}$, Syahrul Syahrul $^{3}$ \\ ${ }^{I}$ Postgraduate Student, Faculty of Nursing, Hasanuddin University; Indonesia \\ ${ }^{2}$ Assistant Professor in Nursing Management Department, Faculty of Nursing, Hasanuddin University, \\ Indonesia \\ ${ }^{3}$ Assistant Professor in Family and Comunity in Nursing Department, Faculty of Nursing, Hasanuddin \\ University, Indonesia. \\ Corresponding author: aisyahsupri21@gmail.com
}

\begin{abstract}
ABSTRAK
Background: One of nursing management functions is organizing nursing staff through assessing their working performances. Managing nursing staff in order to improve their working performance is vital. Thus, it needs to be well-designed to meet the patients' expectation on health care quality. Nurses' performance is defined as the action, achievement, or fulfillment of nurses' responsibilities based on their tasks that have been assigned to them.

Purpose: The aim of this study was to describe the nurses' performance assessment and the nurse activities based on nursing clinical authority at the Dr. Wahidin Sudirohusodo hospital Makassar.

Methods: This research is a qualitative descriptive study. Data were gathered from Focus Group Discussion (FGD), individual interviews, and document analysis.

Results: The study results showed that generally the assessment of the nurses' performances at the Dr. Wahidin Sudirohusodo hospital has been conducted since 2015. However, there were still some areas that need to be improved, such as the quantity indicator assessment that is currently not developed based on the nursing clinical authority. In fact, the assessment of nurses' performance for quantity indicators should be adjusted to the nursing clinical authority that has been assigned to them after completing the credentialing process as stated in the Nurse Clinical Assignment Letter.

Conclusion: The assessment of nurses' performance should be adhered to the nursing clinical authority and it is better if hospital managers may synchronize the nursing clinical authority with the online nursing logbook provided in the Hospital Information System.
\end{abstract}

Keywords: Clinical authority; hospital information system; nursing management; nurse performance assessment; nursing staff.

Received: December 04, 2018; Revised : December 08, 2018; Accepted December 11, 2018

How to Cite: Supri, A., Rachmawaty, R., \& Syahrul, S. (2019). Nurses’ Performance Assessment Based On Nursing Clinical Authority: A Qualitative Descriptive Study. 2(2). 80-90.

https://doi.org/10.30994/jnp.v2i2.48

The Journal of Nursing Practice, its website, and the articles published there in are licensed under a Creative Commons AttributionNonCommercial-ShareAlike 4.0 International License 


\section{BACKGROUND}

Nursing is the biggest profession in health care and it is an important component in efforts to improve the quality of care in health institutions. Profession that works professionally will make a service system effective and efficient. One effort to make professional nurses is through the process of nursing credentials (Needleman, Dittus, Pittman, Spetz, \& Newhouse, 2014)

In the credential process a person will be given clinical authority as a license to do a criminal action which is part of the nurse's performance. Nurse performance is defined as the implementation of an action, achievement or fulfillment of a nurse's responsibilities in accordance with the tasks that have been charged to him (Huber, 2010). Demands for quality care make performance management as the strategy step of an organization that is important to be designed to fulfill consumer expectations for quality health service (Samson, 2009).

In Indonesia, the performance assessment process carried out in several government hospitals generally uses a performance assessment system based on the Employee Work Target (SKP) which is intended for Civil Servants (PNS). This is regulated in the regulation of the minister of empowerment of the state apparatus and bureaucratic reform of the Republic of Indonesia Number 25 of 2014 concerning functional positions of nurses. This assessment regulates the level, position, rank and space class of the functional employees. The application of this performance assessment applies to all government agencies including health workers with civil servant status (Menteri Pemberdayagunaan Aparatur Negara Dan Reformasi Birokrasi., 2014). Assessment based on this SKP is not used for nurses with non-Civil Servant status or contracts, so that some hospitals use different assessments in measuring the performance of all nurses.

In South Sulawesi, Indonesia. Nurse performance assessment in most government hospitals is also applying the SKP scoring system. Personal interviews conducted for a number of nurses' who working in goverment hospitals with civil servant status said that they only used SKP for performance assessment and there was nothing specifically for employees with honorary or contracts status (Herniyanti, 2018, Nurwahidah, 2018, Risal, 2018, Satmayani, 2018). Activities carried out in the framework of monitoring the patient's safety and as an integrated part of performance monitoring that should be carried out by hospital management as required in hospital accreditation. The application of the nurse performance assessment required in the management of nursing management should be based on clinical authority. Nursing actions taken are an ongoing process so that performance and competency monitoring and evaluation are needed (Joint Commission International, 2017)

Process of applying performance assessment to nurses in accordance with the clinical authority of nurses, both health workers with civil servant and non-Civil Servant status are contained in regulations issued by the government in 2013, namely the establishment of nursing committees that function to improve the professionalism of nursing staff working in hospitals and responsible for nurse credentials (Menteri Kesehatan Republik Indonesia., 2013). Since the issuance of the regulation until now, especially government hospitals are still trying to improve clinical governance so that they can improve the quality of hospital services.

Efforts to improve professionalism in the health sector continue to be carried out, one of them is efforts to improve education and skills. However, issues related to patient safety and security continue to follow the quality of health care (Sherwood \& Zomorodi, 2014). Errors in health care contribute to increasing incidents that can result in death, so that security monitoring is needed over time (Landrigan et al., 2010). One study report that 
professional nurses who have clinical competence contribute to effective and efficient of nursing performance (Zhang, Luk, Arthur, \& Wong, 2001). The care given to patients should be ascertained in accordance with the evidence of clinical authority given by the hospital in accordance with the competency of the nurse (Joint Commission International, 2017).

Government efforts to maintain the quality of nursing care services are also outlined in the Minister of Health Regulation (PMK) No. 49 of 2013 concerning the nursing committee and PMK No. 40 of 2017 concerning career paths. The PMK was published to organize and provide opportunities for nursing HR in improving nursing performance through professional nursing careers. In the application of career paths, nurses will be given clinical authority from the hospital related to actions that can be given in carrying out nursing care in accordance with their competencies (PPNI Prov.Sulawesi Selatan, Fakultas Keperawatan Universitas Hasanuddin, RSP Universitas Hasanuddin, \& RSUP Dr. Wahidin Sudirohusodo, 2018).

\section{METHODS}

This research is a descriptive qualitative research. Data collection was carried done in several methods, namely by conducting Focus Group Discussion (FGD), interviews and documentation studies. The. Study was conducted in July 2018 at Dr. Wahidin Sudirohusodo internal nursing room Lontara 1. RSUP. Dr. Wahidin Sudirohusodo was chosen as a research site because the hospital had developed a nurse performance assessment instrument called the Individual Performance Indicator (IKI). This study involved participants who were the actors in the field of performance assessment. The participants consisted of the head of the nursing department, the head of the nursing section, the head of the internal care room, and the nursing committee.

This research begins with the submission to the ethical commission of the Hasanuddin University and applied for permission to research at Dr. Wahidin Sudirohusodo hospital. After obtaining research permission, the research then started by carrying out FGDs together with the nursing management which were participants in this study. After getting the description, the research then continued by conducting a search by doing a documentation study.

\section{RESULT}

\section{FGDs and Intervieuw Data Analysis}

Data was collected throught the FGDs and interviews raises several themes that relate to performance assessment based on clinical nursing outority. The theme that emerges from this method is the basis of performance assessment, the implementation of performance assessment, and the performance assessment obstacle. From theme, there are several sub-theme that are described as follows:

\section{The Basis Of Nurses' Performance Assessment}

Partisipants identify basic application of nurses' performance assessment in RSUP Dr. Wahidin Sudirohusodo.

\section{Remuneration policy}

Participants described the first process of assessing nurses' performance as one of the basis for giving remuneration to nurses. This is illustrated in the following participant statement: 
"Maybe because we are from nursing the program (assessing performance) first because ... we (nursing management) have remunerated " (Participant 1)

" At that time we had a remuneration policy, so that assessment was made"(Participant 2).

The nursing field makes an assessment of nurses' performance as a basis for giving nurses remuneration. Nurse performance is deemed necessary to be assessed to measure the extent to which the performance performed by nurses in carrying out their daily tasks, so that there are indicators that can be used to provide remuneration.

\section{Proof of working}

Performance assessment as an effort to evaluate. Performance is one of proof that the nurse works. This is as stated by partisipants :

"I think that's proof (performance assessment) of someone's performance" (partisipan 5)

"so there must be proof (performance assessment) that we (nurses) is work .” (Partisipan 1)

\section{Implementation of Performance Assessment}

Another theme identified from data analysis is about applying nurses'performance. Performance evaluations that are currently running is assessed based on the nurse logbook that has been integrated by online system. An overview of statements form partisipants indicates a weakness in the existing of logbook:

1. Nursing actions in the logbook are not specific

Nursing actions in nurse performance assessment are the result of the recapitulation of the logbook provided in the hospital information system (SIRS). The logbook provided by the management in an online form is very helpful for nurses in the process of documenting nursing actions, but some weaknesses that arise from providing content in the logbook include actions in the logbook that have not specifically described the nursing area and the actions provided have not fully adjusted clinical authority given to nurses based on the nurse's PK level stated in the SPK-P. Three participants reported related weaknesses of the logbook:

"If I personally, if it is connected between performance and competency according to the PK it has not been mapped yet specific to PK level but indeed in the logbook the work of them can be described. Actually, if in terms of counting the count is proof that it is still general now" (Participant $5)$.

"What is good now is only if it can be modified again ... because there are still many who have not entered the SIRS" (Partisipan 3).

"Our weaknesses in quantity (quantity performance indicators) are nursing actions carried out, all of our actions are not broken" (Partisipan 1). 
Nursing management is currently trying to make improvements. "...that's what we temporarily improve so that the actions in SIRS are made based on the area of nursing. Later, if indeed the action must be appropriate between $P K$ and clinical authority, we will adjust it " (Partisipan 1).

The participant's statement about nursing activities in the logbook illustrates that the actions provided in the logbook have not specifically described the actions per area of nursing and have not fully adjusted to the clinical authority given to nurses based on the level of clinical nurses (PK)

\section{Clinical authority has not run optimally}

Clinical authority given to nurses after going through the credential process has been running in RSUP. Dr. Wahidin Sudirohusodo since 2013. The clinical authority issued in the form of a Nurse Clinical Assignment Letter (SPK-P) is given to nurses based on career level or nurse's PK level. The application of nursing actions based on clinical authority in services is still not running optimally. Some respondents reported an overview of the implementation;

"Actually it is already ... the SPKP that has been signed by the director ... it's just that the nurse himself given a letter of clinical authority not to appreciate what is given" (partisipan 1).

"clinical authority seems to have not been maximally implemented, not yet noticed how the content (SPK-P)" (partisipan 4).

"the room (internal care room) has a team so that the work is divided up, but does not pay attention to clinical authority” (partisipan 4).

The results of interviews with the nursing committee suggested that for the current clinical authority in Dr. Wahidin Sudirohusodo was following a mapping that had been conducted in 2013. From interviews conducted with the nursing committee revealed:

"If the determination of clinical authority ... automatically refers to the determination of PK. Back again to the beginning of 2013 because it has been there since 2013. There are credential guidelines in which there is also clinical authority so we are based on that. So for example, how many PKs do you have ... clinical authority. After we make this white book, we will refer to the white book that has been created. So, in 2013 it was not yet per area; ... children, surgery, interna, ICU, the same type of clinical authority. So PK I, PK II with the same action for one hospital. It actually has a previous revision process but it has not been recorded, then a white book, that's where new per area for example in the clinical authority PKI, PK II and PK III have been arranged. We were guided by that except for $P K I$ generally if the PK I was because it was still considered new, it was generally almost the same because of the basic actions. PK II and PK III are somewhat specific, in accordance with their respective areas ")( (partisipan 7).

\section{Uniform performance targets for all Ward}

In performance assessment, a target is needed to be able to measure the process. Determination of achievement target is still a weakness in the performance 
assessment while working. The right formulation is needed to accommodate each room in determining their respective targets. Some participants reported that the determination of existing targets requires evaluation;

"Our lack of that target yesterday, we took from the number of visits during that year, so that the weakness is that one room could have a room with a low visit but it seems like the target they got" (participant 1)

"... the good thing is perhaps discussed again because usually all this time I see the target ... too high ... while there are also a lot of our work in the room, just keep sharing with other officers ... that's a bit of a problem (participant 3).

"We still use the general one, so it's the same for all Lontara 1 ward ..." (participant 3)

The same statement was also reported by Partisipan 2 and 4 .

The patient's condition, the number of patients, and the types of actions or services provided in each room are different so that the right formulation is needed in determining the target to accommodate each room in adjusting the performance targets that must be achieved by the nurse.

\section{Performance assessment obstacle}

The process of clinical authority-based performance assessment has not run optimally because of several factors. Participants 'statements regarding the contributing factors caused the evaluation of nurses' performance to be in accordance with their authority as follows:

\section{The ratio of nurses and patients is met at a minimum}

One of the themes that emerged in the results of data analysis was the nurse's workload which was associated with the ratio and the number of nurses in the internal care room. Participants' statements illustrate that the ratio of nurses and patients to the room is generally met in a minimum;

"I think in terms of performance, all Indonesian nurses are over-performing in terms of numbers. In terms of the frequency of excessive amounts of activity. Because the

comparison between patients with the number of nurses is less especially the Wahidin Hospital with Type A, obviously the workload is high because the percentage as the final stage of referral leads to severe cases (illness). Maybe only one or two patients are single diagnoses. Here (Dr. Wahidin Sudirohusodo Hospital) it is possible that $95 \%$ are multiple diagnoses. So obviously the workload is very high. So if the workload calculation is high almost every room there are some who should be in total care, and certainly every ward is there ". (Partisipan 5).

The same thing was clarified by another participant that;

"If in terms of our ratio (hospital) is met very minimal." (Participant 2). 
"one ... the nurse has responsibility for the patient, in my room there are 38 so if it's full it means one person handles around 6 patients" (participant 6).

"For the 80\% BOR value, it handles around 35-38 patients per day. Imagine if in per shift there are five nurses ... it means that one person handles six to eight patients per day "(partisipan 4).

\section{Distribution of clinical nurse (PK) is not evenly distributed}

Application of clinical authority that has not been maximized is part of the application of nurse performance that is not fully in accordance with the level of PK in the room. PK level that is not evenly distributed in every room becomes one of the obstacles in implementing nurses' actions in accordance with the nurse's clinical authority. This is illustrated by statements from FGD participants and interview. The following is an illustration that explores the statements of participants about the implementation of actions based on PK:

"Clinical authority now friends are not separated between PK I, PK II, and PK III. All ... it's just that our way is ... if we speak PK II and PK III that are the standard of intensive care space, we from the nursing field place a minimum of PK II in that area. " (partisipan 1)

Sometimes PK I still works PK II work or just helping to do PK II work. They help each other because of the team work system. For actions still not separated. We recommend that in one team there are PK I, PK II, and PK III so that every action is in accordance with the Pk. But now it's not yet ", (partisipan 3).

"If I personally, if it is connected between performance and competency in accordance with the $P K$, it is not yet mapped, not specific to PK" (partisipan 5).

The application of clinical authority that has not been maximized is part of the application of nurse performance that is not fully in accordance with the PK level in the ward. Completion of work is still not really sure that each nurse works according to the evidence of authority given by the hospital.

\section{Dokumen Data Analisys}

Besides collecting data with FGDs and interviews to complete the data, a search was conducted in the internal ward to obtain information related to performance assessment, clinical authority, and the logbook contained in SIRS. The results of the documentation study conducted on several documents found that the SPK-P containing nursing actions based on the nurse's clinical authority has not been adjusted to the actions provided in the logbook which is one of the basis for measuring performance assessment.

There are differences both in terms of the type of the action and the suitability of the language in the nurse's SPK-P with those in the logbook. The list of actions provided is united for all actions for one hospital so that there is no difference in the authority of action for PK I, II, and so on. 
From the results of the documentation study for performance assessment documents, it was described that performance assessment was accompanied by performance indicators, targets and performance achievements. Nursing management divides performance into four indicators namely; indicators of quality, quantity, work behavior and additional activities. Quality indicators are given a weight of 30\%, a $30 \%$ quantity indicator, $30 \%$ work behavior and an additional $10 \%$ activity. Quantity indicators are achieved from the results of the activities of providing nursing care and the implementation of actions that are reviewed from the daily logbook of nurses who are then confined for one month. For quality indicators is the result of monitoring and evaluation of the head of the ward to the nurses. Indicators of work behavior and additional activities are also the results of monitoring and evaluating the head of the ward on the work behavior shown by the nurse.

\section{DISCUSSION}

Various problems related to the implementation of performance assessment are a challenge for an organization to be able to regulate its labor resources. From the results of research on the performance assessment of nurses who applied in RSUP. Dr. Wahidin Sudirohusodo found that the remuneration policy became the initial basis of the nursing management to compile the nurse's performance assessment. Management support to improve quality one of them is by considering the welfare of nursing staff. This is in line with research which states that organizational support can positively affect job satisfaction and have implications for improving job performane (Gillet, Colombat, Michinov, Pronost, \& Fouquereau, 2013)

Problems related to content in logbooks that are not specific to be a challenge for organizations to make modifications. Existing nursing actions should adjust to the clinical authority of nursing so that it will synchronize between the SPK-P authority letter provided with the list of actions provided in the logbook that has been integrated into SIRS. A study describing the performance assessment problems that commonly occur with regard to performance assessment are contextual problems, performance assessment structures, and performance assessment results (Nikpeyma, Saeedi, Azargashb, \& Majd, 2014). Nursing management efforts at Dr. Wahidin Sudirohusodo in the documentation process using a technology framework, is what facilitates nurses in the process of documenting daily activities in the form of computerized logbooks. These findings reflect some of the research results that illustrate how a documentation process can have a positive impact on quality, assessment, access to information and can cut down the worker's time so that the patient's treatment time is not taken up (Bonenberger, Aikins, Akweongo, \& Wyss, 2014; Rachmawaty, 2015; Wang \& Grossman, 2006).

Problems related to not maximizing the application of performance assessment based on the clinical authority of nursing is a challenge for the management to make renewal considering that in a health organization various policies and rules always change, so that alignment is needed from every related aspect. Includes policies for performance assessment requirements based on clinical nursing authority. National Hospital Accreditation Standards (SNARS) require that the fulfillment of the need to provide nursing care is carried out by considering the aspects of education, competence, knowledge and experience of staff. In other words, the credentials that gave birth to clinical authority became a requirement in the provision of nursing care (KARS, 2017). The credential system limits the authority by ensuring that care provided to patients is carried out by professional nurses in accordance with their competencies. This is also due to the incompatibility between nurse logbooks that have been provided in online form and 
clinical authority in SPK-P. Monitoring and evaluation should be carried out systematically on performance and competence so that the actions provided can adjust to the existing clinical authority (Joint Commission International, 2017)

One of the problems that can arise in the performance assessment process is the provision of performance targets. Performance targets should be given to adjust to the conditions in the treatment room. Various things should be considered because the conditions of the room and nursing area is different. In determining the target, the nursing management should consider aspects of justice. A literature describing the existence of procedural justice in an organization significantly supports and provides a positive influence on job satisfaction and job performance (Gillet et al., 2013)

From the aspect of nurse ratio, it was found that on average nurses on duty were responsible for 5-7 per sifted patients. Meanwhile the standard ratio of patient nurses for type A hospitals as described in the health minister's regulation No. 56 of 2014 explains that the number of nursing staff needs is equal to the number of beds in inpatient installations (Menteri Kesehatan Republik Indonesia., 2014). A survey study conducted in 655 hospitals in the United State states that the high ratio between patients and patients has the potential to increase the likelihood of patient death and failure to save patients (Aiken et al., 2011).

One of the things that causes the implementation of nursing clinical authority activities has not been maximized is the division of PK that is not evenly distributed in every room. There is an increase in service at RSUP. Dr. Wahidin Sudirohusodo such as the establishment of Integrated Heart Disease (PJT) services requires many nursing staff with a minimum level of competency PK II. This situation absorbed a lot of energy with a high level of PK in the previous room, thus giving an influence on the inequality of the distribution of clinic nurses (PK) in the room including internal care. This has become one of the obstacles so that the implementation of the existing measures in accordance with the PK level has not run optimally.

\section{CONCLUSION}

There are many things that management must pay attention to in nursing governance. One of them is nursing performance. Measured and well-documented, can be the basis for evaluating the quality of nursing services. Professionalism performance can be realized one of them by applying the provision of nursing care based on nursing clinical competence in the form of limitation of authority. A nurse who is able to work in accordance with clinical competence will be more confident in working so that it can improve his satisfaction and also patient satisfaction with the services provided.

Computerized documentation needs to be considered in the performance assessment process because it can help nurses and managers in managing services. In addition, the development of existing performance assessment is expected to help management in an effort to evaluate and tiered supervision for the room in improving the competence of its nurses.

\section{ACKNOWLEDGMENT}

This research is part of the researcher's final assignment process in completing a master program in the field of nursing. A very large contribution from RSUP hospital management. Dr. Wahidin Sudirohusodo and Postgraduated program, faculty of Nursing, really helped the writer in completing this research. 


\section{REFERENCES}

Aiken, L., Cimioti, J., Sloane, D., Smith, H., Flynn, L., \& Neff, D. F. (2011). Effects of nurse staffing and nurse education on paitent deaths in hospitals with differnt nurse work environment. Medical Care, 49(12), 1047-1053. https://doi.org/10.1097/MLR.0b013e3182330b6e

Bonenberger, M., Aikins, M., Akweongo, P., \& Wyss, K. (2014). The effects of health worker motivation and job satisfaction on turnover intention in Ghana : a crosssectional study. Human Resources For Health, 1-12.

Gillet, N., Colombat, P., Michinov, E., Pronost, A., \& Fouquereau, E. (2013). Procedural justice, supervisor autonomy support, work satisfaction, organizational identification and job performance: the mediating role of need satisfaction and perceived organizational support. Journal Of Advance Nursing. https://doi.org/10.1111/jan.12144

Huber, D. L. (2010). Leadership and Nursing Care Management. Saunders Elsevier (Vol. Fourth Edi). https://doi.org/10.1007/s13398-014-0173-7.2

Joint Commission International. (2017). Standar Akreditasi Rumah Sakit Joint Commission International, Termasuk Standar Untuk Rumah Sakit Pendidikan. PT. Trans Medical International, Jakarta pust.

KARS. (2017). Standar Nasional Akreditasi Rumah Sakit Edisi 1. https://doi.org/10.15713/ins.mmj.3

Landrigan, C. P., Parry, G. J., Bones, C. B., Hackbarth, A. D., Goldmann, D. A., \& Sharek, P. J. (2010). Temporal Trends in Rates of Patient Harm Resulting from Medical Care. New England Journal of Medicine, 363(22), 2124-2134. https://doi.org/10.1056/NEJMsa1004404

Menteri Kesehatan Republik Indonesia. Peraturan Menteri Kesehatan., Pub. L. No. 49, 1 (2013). Jakarta, Indonesia.

Menteri Kesehatan Republik Indonesia. Peraturan Menteri Kesehatan Republik Indonesia, Pub. L. No. 56 (2014). jakarta, Indonesia.

Menteri Pemberdayagunaan Aparatur Negara Dan Reformasi Birokrasi. Peraturan Menteri Pemberdayagunaan Aparatur Negara Dan Reformasi Birokrasi Republik Indonesia., Pub. L. No. 25 (2014). Jakarta, Indonesia.

Needleman, J., Dittus, R. S., Pittman, P., Spetz, J., \& Newhouse, R. (2014). Nurse credentialing research frameworks and perspectives for assessing a research agenda.

Nikpeyma, N., Saeedi, Z. A., Azargashb, E., \& Majd, H. A. (2014). Problems of Clinical Nurse Performance Appraisal System : A Qualitative Study. Asian Nursing Research., 8. https://doi.org/10.1016/j.anr.2013.11.003

PPNI Prov.Sulawesi Selatan, Fakultas Keperawatan Universitas Hasanuddin, RSP Universitas Hasanuddin, \& RSUP Dr. Wahidin Sudirohusodo. (2018). Buku Putih 33 Area Keperawatan (RS Universitas Hasanuddin \& RSUP Dr. Sudirohusodo). Makassar-Sulawesi Selatan: PT Isam Cahaya Indonesia.

Rachmawaty, R. (2015). The Development Of The Electronic Nursing Record System (ENRS) In The Hospital Setting: An Integrative Literature Review. American Journal of Health Sciences., 6(1), 1-6.

Samson, R. (2009). Leadership And Management in Nursing Practice and Education. New Delhi: Jaypee Brothers Medical Publisher (P) Ltd.

Sherwood, G., \& Zomorodi, M. (2014). A new mindset for quality and safety: The QSEN competencies redefine nurses' roles in practice. Journal of Nursing Administration, 44(10), 15-22. https://doi.org/10.1097/NNA.0000000000000124

Wang, J., \& Grossman, H. T. (2006). Electronic Versus Paper-Based Nursing 
documentation Systems: The Cargivers Weight In.

Zhang, Z. X., Luk, W., Arthur, D., \& Wong, T. (2001). Nursing competencies: Personal characteristics contributingto effective nursing performance. Journal of Advanced Nursing, 33(4), 467-474. https://doi.org/10.1046/j.1365-2648.2001.01688.x 